\title{
GRUNTY ROLNE ZAJĘTE NA PROWADZENIE DZIAŁALNOŚCI GOSPODARCZEJ A PODATEK OD NIERUCHOMOŚCI
}

Streszczenie. W artykule omówione zostały kwestie związane z opodatkowaniem podatkiem od nieruchomości gruntów rolnych zajętych na prowadzenie działalności gospodarczej. Pojęcie gruntów zajętych na działalność gospodarczą nie jest uregulowane wprost w polskich przepisach. W artykule została więc przeprowadzona analiza orzecznictwa sądowego, wykładni systemowej oraz poglądów pojawiających się w doktrynie.

Słowa kluczowe: Grunty, podatek od nieruchomości, zajęcie, działalność gospodarcza

1. WstęP

Zgodnie z obowiązującymi przepisami dotyczącymi opodatkowania nieruchomości z daniny tej wyłączone są użytki rolne lub lasy, z wyjątkiem zajętych na prowadzenie działalności gospodarczej. Regulacja ta ma duże praktyczne znaczenie dla podatników, gdyż stawki podatku od nieruchomości mogą być wielokrotnie wyższe niż stawki w podatku rolnym. Właściwa interpretacja pojęcia „zajęcia na prowadzenie działalności gospodarczej" pozwoli prawidłowo zakwalifikować dany grunt i w konsekwencji określić jakim podatkiem zostanie obciążony.

Pojęcie to nie jest jednak zdefiniowane w ustawodawstwie podatkowym a jego wykładnia budzi wątpliwości zarówno w orzecznictwie sądów

* Doktorantka w katedrze Prawa Podatkowego na Wydziale Prawa i Administracji UŁ. 
administracyjnych jak i w doktrynie prawa podatkowego. Analizując więc zakres pojęcia zajęcia na działalność gruntu rolnego, należy w przeważającej mierze odnieść się do orzecznictwa sądowego, wykładni systemowej oraz poglądów pojawiających się w doktrynie.

\section{Przepisy ustawy o PODATKaCH LOKALNYCH A OPODATKOWANIE GRUNTU ROLNEGO PODATKIEM OD NIERUCHOMOŚCI}

Obowiązujące w Polsce przepisy dotyczące opodatkowania nieruchomości zostały uregulowane $\mathrm{w}$ ustawie o podatkach i opłatach lokalnych ${ }^{1}$. Zgodnie $\mathrm{z}$ art. 2 ust. 1, opodatkowaniu podatkiem od nieruchomości podlegają następujące nieruchomości lub obiekty budowlane:

1) grunty;

2) budynki lub ich części;

3) budowle lub ich części związane z prowadzeniem działalności gospodarczej.

Zgodnie z ustępem 2 powyższego przepisu, opodatkowanie podatkiem od nieruchomości nie podlegają użytki rolne lub lasy, z wyjątkiem zajętych na prowadzenie działalności gospodarczej.

Zgodnie $\mathrm{z}$ art. 1a u.p.o.l. przez użyte $\mathrm{w}$ ustawie określenia:

- użytki rolne,

- lasy,

- nieużytki,

- użytki ekologiczne,

- grunty zadrzewione i zakrzewione,

- (uchylony),

- grunty pod wodami powierzchniowymi stojącymi oraz grunty pod wodami powierzchniowymi płynącymi,

- grunty pod morskimi wodami wewnętrznymi

rozumie się grunty sklasyfikowane w ten sposób w ewidencji gruntów i budynków.

Z powyższej regulacji wyprowadzić należy wniosek, że pierwszym i podstawowym kryterium decydującym o zaliczeniu danego przedmiotu do opodatkowania podatkiem od nieruchomości, rolnym, czy też leśnym, jest klasyfikacja gruntu w ewidencji gruntów i budynków. Sklasyfikowanie

${ }^{1}$ Ustawa z 12 stycznia 1991 r. o podatkach i opłatach lokalnych (Dz.U.2017.1785 tj. z dnia 27 września 2017 r., dalej: u.p.o.l.). 
gruntu w tym rejestrze ma podstawowe znaczenie w kontekście prawidłowego wymiaru podatku, co wynika z prawa geodezyjnego i kartograficznego. Zgodnie więc $\mathrm{z}$ regulacjami ustawowymi, co do zasady, grunty sklasyfikowane w ewidencji jako grunty rolne nie podlegają podatkowi od nieruchomości.

Od wskazanej powyżej reguły istnieje jednak wyjątek i jest nim okoliczność zajęcia gruntu na prowadzenie działalności gospodarczej. Zatem grunty sklasyfikowane w ewidencji jako użytki rolne powinny zostać opodatkowane podatkiem rolnym, chyba że grunty te zostały zajęte na prowadzenie działalności gospodarczej, wówczas podlegają opodatkowaniu podatkiem od nieruchomości.

\section{ZNACZENIE WPISU W EWIDENCJI A UZNANIE GRUNTU ZA GRUNT ROLNY}

Jak wcześniej zostało wskazane, wymiarowi podatku dokonywanemu przez wójta, burmistrza czy prezydenta właściwego miejscowo ze względu na położenie przedmiotu opodatkowania w pierwszej kolejności powinny służyć dane zawarte w ewidencji gruntów i budynków.

Zgodnie z poglądem wyrażanym w orzecznictwie sądowym dane zawarte w ewidencji gruntów i budynków stanowią dokument urzędowy w rozumieniu art. $194 \$ 1$ O.p. ${ }^{2}$ Oznacza to, że przy rozbieżnych informacjach o funkcji lub sposobie wykorzystania prymat należy dać informacjom z ewidencji gruntów i budynków. Dlatego dla celów opodatkowania gruntu nie ma znaczenia na jakie cele jest on wykorzystywany (za wyjątkiem działalności gospodarczej), a jedynie oznaczenie w ewidencji gruntów i budynków.

Przepis art. 2 ust. 2 u.p.o.l. należy zatem uznać za wyjątek od zasady związania organów podatkowych danymi wynikającymi z ewidencji gruntów i budynków. Aby określić wysokość podatku od nieruchomości należy więc w pierwszej kolejności sprawdzić oznaczenie gruntu w ewidencji a dane wynikające $z$ ewidencji gruntów i budynków stanowią dowód tego, co zostało w nich urzędowo stwierdzone. Kwestią sporną w doktrynie prawa podatkowego jest ustalenie czy organ podatkowy ma prawo pominąć dane wynikające $z$ ewidencji, jeżeli są one niezgodne ze stanem rzeczywistym

${ }^{2}$ Zob. wyrok Wojewódzkiego Sądu Administracyjnego w Gliwicach z dnia 17 stycznia 2018 r. I SA/Gl 1115/17. Wszystkie wskazane w niniejszym artykule wyroki są dostępne w Centralnej Bazie Orzeczeń Sądów Administracyjnych. 
i dokonać wymiaru podatku w oparciu o faktyczne przeznaczenie nieruchomości ${ }^{3}$. Zgodnie z przepisami o.p., należy przyjąć, że organy mają taką możliwość i mogą podważyć wartość dowodową dokumentu urzędowego jakim jest ewidencja gruntów i budynków. Dane wynikające z ewidencji mogą być podważone jedynie w przypadku, gdy są niezgodne ze stanem rzeczywistym. A contrario, gdy dane zawarte w ewidencji odpowiadają stanowi faktycznemu i rzeczywistemu przeznaczeniu i użytkowaniu gruntu, dane takie nie powinny być przez organ kwestionowane.

Powyższe oznacza więc, że jeżeli w posiadaniu podatnika są użytki rolne lub lasy (co wynika z ewidencji), to, co do zasady, nie podlegają opodatkowaniu podatkiem od nieruchomości, chyba że są zajęte na prowadzenie działalności gospodarczej. Grunty takie nie są natomiast zajęte wtedy, gdy pomimo posiadania ich przez przedsiębiorcę są wykorzystywane zgodnie z przeznaczeniem klasyfikacyjnym, a więc na działalność rolną lub leśną ${ }^{4}$. Nie ma więc żadnych podstaw dowodzenie istnienia zajęcia gruntu rolnego na działalność gospodarczą, gdy grunt rolny wykorzystywany jest zgodnie z jego klasyfikacyjnym przeznaczeniem, a więc prowadzona jest na nim działalność rolna.

Ponadto NSA wypowiedział się również na temat znaczenia regulacji z zakresu prawa geodezyjnego i kartograficznego dla wymiaru podatku. W wydanym 13 stycznia 2015 orzeczeniu ${ }^{5}$ wskazał m.in., że w orzecznictwie sądów dość powszechnie przyjmowany jest pogląd, w świetle którego organ podatkowy nie może samodzielnie dokonywać klasyfikacji nieruchomości, lecz powinien odwołać się do odpowiednich zapisów ewidencji gruntów i budynków.

W innych orzeczeniach NSA wskazywał jednak na przypadki, w których ta reguła bezwzględnego związania danymi ewidencyjnymi może zostać w ramach postępowania podatkowego podważona, nawet bez potrzeby uprzedniej zmiany samej ewidencji ${ }^{6}$. Odstępstwo od tej reguły przykładowo może mieć miejsce w sytuacji, gdy informacje zawarte w ewidencji gruntów i budynków pozostają w sprzeczności z danymi zamieszczonymi w innych rejestrach

${ }^{3}$ E. Zaniewicz, Wpływ ewidencji gruntów i budynków na podatek od nieruchomości, https://sip.lex.pl/\#/publication/469910859/zaniewicz-edyta-wplyw-ewidencji-gruntow-i-budynkow-na-podatek-od-nieruchomosci?cm=RELATIONS (dostęp: 20.04.2018).

${ }^{4}$ Por. wyrok NSA z dnia 12 kwietnia 2017 r., II FSK 784/15.

5 Tak orzekł Naczelny Sąd Administracyjny w wyroku z dnia 13 stycznia 2015 r., sygn. akt II FSK 3108/12, w którym powołano m.in. uchwałę siedmiu sędziów NSA z dnia 27 kwietnia 2009 r., sygn. akt II FPS 1/09.

${ }^{6}$ W uchwale składu siedmiu sędziów z dnia 18 listopada 2013 r., sygn. akt II FPS 2/13, NSA wskazał jednak na przypadki. 
publicznych, których pierwszeństwo wynika z bezwzględnie obowiązujących przepisów, lub też w przypadku, gdy posłużenie się wyłącznie danymi ewidencyjnymi musiałoby się wiązać z pominięciem przepisów zawartych w ustawie podatkowej, mających wpływ na wymiar podatku (możliwe do zastosowania symbole ewidencyjne nie przewidują oznaczenia dla pewnych przedmiotów opodatkowania wymienionych wprost w ustawie podatkowej).

$\mathrm{W}$ orzecznictwie sądowym można również spotkać się $\mathrm{z}$ podziałem danych zawartych w ewidencji ze względu na ich moc wiążącą. W tym zakresie NSA, wskazał, że uwzględniając kryterium mocy wiążącej ewidencji gruntów i budynków dla wymiaru podatku, tj. ustalenia elementów przedmiotowych i podmiotowych zobowiązania podatkowego, zawarte w niej informacje można podzielić na dwie kategorie ${ }^{7}$. Pierwszą z nich tworzą dane bezwzględnie wiążące organ podatkowy, zaś drugą - informacje o względnej mocy wiążącej, tj. takie, których zgodność z rzeczywistym stanem prawnym lub faktycznym może być przy wymiarze podatku weryfikowana, przy zastosowaniu dopuszczalnych instrumentów procesowych (art. $180 \$ 1$ w zw. z art. $194 \$ 3$ ustawy z dnia 29 sierpnia 1997 r. - Ordynacja podatkowa, Dz.U. z 2015 r., poz. 613).

- Do pierwszej grupy zaliczyć można dane ewidencyjne wskazujące położenie, granice i powierzchnię gruntów oraz rodzaj użytków gruntowych i klasy gleboznawcze, a w odniesieniu do budynków i lokali stanowiących odrębny przedmiot własności także informacje dotyczące ich położenia, przeznaczenia, funkcji użytkowych i powierzchni użytkowej lokali (art. 20 ust. 1 Prawa geodezyjnego i kartograficznego).

- W drugiej grupie znajdą się natomiast dane dotyczące tych elementów przedmiotowych, które zostały wskazane w ustawie podatkowej (jako podlegające opodatkowaniu bądź nie), a jednocześnie przepisy dotyczące prowadzenia ewidencji gruntów i budynków nie przewidują dla tych kategorii oznaczenia stosownym, skonkretyzowanym symbolem (uchwała z dnia 18 listopada 2013 r., sygn. akt II FPS 2/13), czy też np. dane dotyczące zlokalizowanych na działce gruntu budynków, które w rzeczywistości nie istnieją (wyrok NSA z dnia 5 czerwca 2014 r., sygn. akt II FSK 1647/12).

Co do zasady, organy podatkowe są więc związane danymi wynikającymi z ewidencji a kwestionować je mogą w sytuacjach wyjątkowych. W odniesieniu do możliwości opodatkowania gruntu rolnego podatkiem od nieruchomości oznacza to, iż każdorazowo organ powinien badać szczegółowo

${ }^{7}$ Zob. m.in. wyrok z dnia 26 września 2014 r., sygn. akt II FSK 3099/12. 
stan faktyczny i zakres działań wykonywanych na danym gruncie. Dopiero taka szczegółowa analiza pozwoli na ustalenie czy doszło do zajęcia gruntu na prowadzenie działalności gospodarczej a w konsekwencji czy możliwe będzie opodatkowanie go podatkiem od nieruchomości.

\section{Pojęcie zajęCia gruntu na Prowadzenie}

\section{DZIAŁALNOŚCI GOSPODARCZEJ}

Jak już wcześniej zostało wskazane, pojęcie „zajęcie na prowadzenie działalności gospodarczej” nie zostało zdefiniowane na gruncie u.p.o.l. a jego zakres budzi wiele wątpliwości w orzecznictwie sądów administracyjnych oraz w doktrynie prawa podatkowego.

Przepis art. 1a ust. 1 pkt 4 u.p.o.l. definiuje działalność gospodarczą jako działalność, o której mowa w ustawie z dnia 2 lipca 2004 r. o swobodzie działalności gospodarczej.

Przepisy u.p.o.l. wprowadzają jednak ograniczenie definicji działalności gospodarczej z ww. ustawy o swobodzie działalności gospodarczej ${ }^{8}$. Jak wskazuje się bowiem w art. 1a ust. 2 u.p.o.l. dla celów podatku od nieruchomości, nie uważa się za działalność gospodarczą:

a) działalności rolniczej lub leśnej, przy czym trzeba tu zaznaczyć, iż działalności te zostały zdefiniowane analogicznie w przepisach u.p.ol., jak i w przepisach u.p.r. oraz przepisach u.p.l.;

b) wynajmu turystom pokoi gościnnych w budynkach mieszkalnych znajdujących się na obszarach wiejskich przez osoby ze stałym miejscem pobytu w gminie położonej na tym terenie, jeżeli liczba pokoi przeznaczonych do wynajęcia nie przekracza 5;

c) działalności, o której mowa w art. 3 pkt 4 ustawy z dnia 2 lipca 2004 r. o swobodzie działalności gospodarczej, tj. działalności rolników w zakresie sprzedaży, o której mowa w art. 20 ust. 1c ustawy z dnia 26 lipca 1991 r. o podatku dochodowym od osób fizycznych, tj. działalności rolników, z której osiągane przychody klasyfikowane są do źródła przychodów z innych źródeł dla celów podatku dochodowego od osób fizycznych.

Działalnością gospodarczą w rozumieniu $\mathrm{z}$ art. 1a ust. 1 pkt 4 u.p.o.l. w zw. z art. 2 ustawy z 2 lipca 2004 r. o swobodzie działalności gospodarczej

${ }^{8}$ I. Podedworna, K. Wojtowicz-Janicka, Grunty jako przedmiot podatku od nieruchomości [online], 23.04.2018 21:20, https://sip.lex.pl/\#/publication/469833093 (dostęp: 25.04.2018). 
jest „zarobkowa działalność wytwórcza, budowlana, handlowa, usługowa oraz poszukiwanie, rozpoznawanie i wydobywanie kopalin ze złóż, a także działalność zawodowa, wykonywana w sposób zorganizowany i ciągły”.

Z przytoczonej powyżej definicji działalności gospodarczej wynika więc, że jednoznaczną podstawą do opodatkowania podatkiem od nieruchomości gruntów rolnych będzie fakt ich zajęcia na działalność gospodarczą, czyli rzeczywiste i trwałe wykonywanie na nich czynności składających się na prowadzenie działalności gospodarczej. Ponadto, muszą to być czynności wykonywane w sposób trwały i wykluczający prowadzenie innej działalności, w tym przypadku rolnej'.

W orzecznictwie sądów administracyjnych podkreśla się, że nie można mówić o zajęciu użytków rolnych lub lasów na prowadzenie działalności gospodarczej, gdy mimo posiadania ich przez przedsiębiorcę grunty takie są wykorzystywane zgodnie z przeznaczeniem klasyfikacyjnym, a więc na działalność rolną lub leśną, natomiast o zajęciu użytków rolnych lub lasów na prowadzenie działalności gospodarczej świadczą podjęte wobec tych gruntów działania, przede wszystkim faktyczne obejmujące cały kompleks nieruchomości ${ }^{10}$.

Warto ponadto pokreślić, że pojęcie zajęcia gruntu na prowadzenie takiej działalności jest pojęciem różnym od gruntu związanego z prowadzeniem takiej działalności, zdefiniowanego w art. 1 ust. 1 pkt 3 u.p.o.l. Grunt zajęty na prowadzenie działalności gospodarczej to taki, na którym działalność taka faktycznie jest prowadzona, w postaci wykonywania aktów takiej działalności, jak także grunty funkcjonalnie związane z taką działalnością, bez których nie byłoby możliwe jej prowadzenie z przyczyn określonych przez przepisy, bądź też okoliczności faktycznych jej prowadzenia. Działalność gospodarcza nie może przy tym polegać na prowadzeniu działalności rolniczej bądź leśnej. „Grunt związany z prowadzeniem działalności” to pojęcie znacznie szersze znaczeniowo i obejmuje więcej stanów faktycznych niż pojęcie „zajęcia na działalność gospodarczą”. W tym zakresie na uwagę zasługują liczne orzeczenia NSA potwierdzające różnice między pojęciem zajęcia a związania z działalnością gospodarczą ${ }^{11}$.

${ }^{9}$ Takie stanowisko zajął m.in. WSA w Gliwicach w wyroku z dnia 17 stycznia $2018 \mathrm{r}$. I SA/Gl 1115/17.

${ }^{10}$ Por. wyrok NSA z dnia 14 maja 2015 r., II FSK 190/15.

${ }^{11} \mathrm{~W}$ orzecznictwie sądów administracyjnych przyjmuje się zgodnie, że do uznania danego obiektu za związany z prowadzeniem działalności gospodarczej nie jest konieczne wykorzystywanie nieruchomości na cele związane z działalnością gospodarczą, bowiem 
Dokonując wykładni językowej nie sposób przyjąć, iż pojęcie użytki rolne, grunty zadrzewione i zakrzewione na gruntach rolnych lub lasy „zajęte na prowadzenie działalności gospodarczej” jest tożsame z pojęciem gruntu „Związanego z działalnością gospodarczą”. Na gruncie wykładni prawa powszechnie obowiązującego regułą kardynalną jest zasada racjonalności ustawodawcy, nakazująca przyjąć, iż brzmienie konkretnego przepisu prawa jest zabiegiem celowym ustawodawcy, a nie jest to działanie przypadkowe. Skoro zatem ustawodawca posługuje się dwoma odmiennymi sformułowaniami prawnymi, tj.: „grunty związane z działalnością gospodarczą” oraz „grunty zajęte na prowadzenie działalności gospodarczej” to nie mogą to być pojęcia zamienne.

\section{Przesłanki uZnania, że dany grunt Jest zajęty} NA PROWADZENIE DZIAŁALNOŚCI GOSPODARCZEJ

Jak zostało już wcześniej podkreślone, zajęcie gruntu na prowadzenie działalności gospodarczej polega na faktycznym jego wykorzystywaniu w tej działalności. Między innymi może to polegać na traktowaniu danego gruntu jako pewnego rodzaju przestrzeni służącej wykonywaniu określonego rodzaju działalności gospodarczej. Konieczne jest jednak w każdym przypadku wykazanie bezpośredniego związku danego gruntu z wykonywaną działalnością gospodarczą.

$\mathrm{Na}$ konieczność ustalenia faktycznego sposobu wykorzystania gruntu wskazał również Trybunał Konstytucyjny w wyroku z dnia 12 grudnia 2017 r. (SK 13/15). Zdaniem Trybunału, „samo prowadzenie działalności gospodarczej przez osobę fizyczną nie jest relewantne dla opodatkowania gruntu stawką podatkową od gruntów związanych z prowadzeniem działalności gospodarczej (określoną w art. 5 ust. 1 pkt 1 lit. a) u.p.o.l.). Zważywszy na ratio stosowania podwyższonej stawki, jaką jest potencjalna możliwość uzyskiwania przychodów z wykorzystania danych gruntów, niezbędne jest ustalenie faktycznego sposobu wykorzystania opodatkowanego gruntu, którego współposiadaczem pozostaje osoba fizyczna prowadząca

wystarczy sam fakt jej posiadania przez przedsiębiorcę. Pojęcie budynków „związanych z prowadzeniem działalności gospodarczej” jest szersze od pojęcia „zajętych na prowadzenie działalności gospodarczej” i obejmuje także pośrednie związanie budynku lub jego części z działalnością gospodarczą" (wyrok NSA z dnia 27 lutego 2014 r., sygn. akt II FSK 854/12; podobnie wyroki z dnia 27 lutego 2014 r., sygn. akt II FSK 855/12 i sygn. akt II FSK 857/12). 
działalność gospodarczą”. Wyrok ten w głównej mierze odnosi się do kwestii podatników będących osobami fizycznymi, lecz TK odniósł się również do ogólnych kwestii uznania gruntu za związany z działalnością gospodarczą, stwierdzając, iż norma prawna, według której do zakwalifikowania gruntu podlegającego opodatkowaniu podatkiem od nieruchomości do kategorii gruntów związanych z prowadzeniem działalności gospodarczej wystarczy prowadzenie działalności gospodarczej przez osobę fizyczną będącą jego współposiadaczem, wywołuje skutki, których nie da się pogodzić z zasadami wyrażonymi w Konstytucji, co również wskazuje na konieczność każdorazowego badania sytuacji faktycznej. Wyrok ten choć jest niewątpliwie korzystny dla podatników i spotkał się z aprobatą ${ }^{12}$ to daje pewne uzasadnienie do uznania, iż opodatkowane podatkiem od nieruchomości mogą zostać te grunty, które potencjalnie mogą być wykorzystywane w prowadzonej działalności gospodarczej.

Użyte przez ustawodawcę sformułowanie "grunty zajęte na prowadzenie działalności gospodarczej” oznacza, że na gruncie muszą być wykonywane rzeczywiste czynności składające się na prowadzenie działalności gospodarczej. Czynności te muszą być wykonywane w sposób trwały i tak, że w zasadzie wykluczają prowadzenie innej działalności (w tym rolniczej). Jeżeli natomiast wydzierżawiony czy też nabyty grunt sklasyfikowany jako rolny jest w posiadaniu przedsiębiorcy, który nie wykorzystuje go na prowadzenie działalności, to nie ma podstaw do opodatkowania tego gruntu podatkiem od nieruchomości. Do zajęcia gruntu na prowadzenie działalności gospodarczej bez wątpienia dojdzie również w przypadku, gdy przedsiębiorca podejmie na gruncie czynności zmierzające do osiągnięcia przychodu., w tym także czynności przygotowawczych, m.in. polegających

${ }^{12} \mathrm{~W}$ glosie aprobującej do wyroku TK z dnia 12 grudnia 2017 r., SK 13/15 odniesiono się m.in. do fragmentu uzasadnienia wyroku TK, w którym wskazano, że ratio stosowania podwyższonej stawki podatku od nieruchomości jest potencjalna możliwość uzyskiwania przychodów z wykorzystywania przedmiotu opodatkowania. „Podkreślenie tej kwestii prowadzi do wniosku, iż TK nie zanegował stosowania wyższej stawki podatku od nieruchomości również w zakresie tych gruntów czy budynków, które faktycznie nie są wykorzystywane do prowadzenia działalności gospodarczej (nie są zajęte na prowadzenie takiej działalności), ale potencjalnie mogą być. W dalszym ciągu zatem aktualny pozostaje pogląd, wedle którego do nieruchomości związanych z prowadzeniem działalności gospodarczej zaliczone powinny być także te grunty i budynki, które przejściowo nie są wykorzystywane przez podatnika w prowadzonej działalności gospodarczej, ale ich cechy powodują, że realnie mogą być one wykorzystywane na ten cel”. R. Dowgier, Glosa do wyroku TK z dnia 12 grudnia 2017 r., SK 13/15, ZNSA 2018/3, s. 133-142. 
na budowie inwestycji przeznaczonej do tej działalności. Chodzi tutaj o działania faktyczne na gruncie polegające na ingerencji w grunt w taki sposób, aby powodowały one zmiany w gruncie uniemożliwiające jego wykorzystanie jako grunt rolny, tj. rozpoczęcie działań na gruncie lub jego wyłączenie z produkcji rolnej. Również użytkowanie gruntu rolnego jako pomocniczego dla gruntów, na których podatnik prowadzi działalność gospodarczą (np. poprzez poprowadzenie na nim drogi dojazdowej czy zainstalowanie infrastruktury energetycznej) może zostać uznane za zajęcie gruntu na działalność gospodarczą.

Korzystne dla podatników stanowisko zajął również w odpowiedzi z dnia 12 lipca 2005 r. na zapytanie nr 4227 z dnia 15 czerwca 2005 r. w sprawie sposobu opodatkowania gruntów wykorzystywanych pod zabudowę wyciągów narciarskich oraz na zjazdy dla narciarzy podsekretarz stanu w Ministerstwie Finansów stwierdzając, iż

zajęcie gruntów rolnych na działalność gospodarczą oznacza ich faktyczne wykorzystywanie na działalność gospodarczą niebędącą działalnością rolniczą. [...] Sumując, należy stwierdzić, że jeżeli grunty rolne są zajęte na działalność gospodarczą okresowo (kilka miesięcy w roku), przez ten okres opodatkowane są one podatkiem od nieruchomości ze stawką właściwą dla przedmiotów opodatkowania zajętych na prowadzenie działalności gospodarczej, a przez pozostałą część roku - podatkiem rolnym.

Tym bardziej, nie sposób uznać, że w przypadku, gdy przedsiębiorstwo nie rozpoczęło i nie prowadziło działalności gospodarczej na gruncie zastosowanie znajdzie opodatkowanie podatkiem od nieruchomości.

Wątpliwości pod kątem uznania gruntu za zajęty na działalność gospodarczą pojawiały się również w zakresie posiadania przez przedsiębiorcę koncesji obejmującej grunty sklasyfikowane jako rolne. Obecnie, nie ma już w praktyce problemów z opodatkowaniem gruntów w trakcie rekultywacji. Przyjmuje się, że powinny one być opodatkowane stawkami najwyższymi podatku od nieruchomości, aż do czasu zakończenia rekultywacji ${ }^{13}$. Opodatkowaniu podatkiem od nieruchomości mogą bowiem podlegać grunty rolne w sytuacji, gdy przedsiębiorca faktycznie na danym gruncie prowadzi działalność gospodarczą polegającą na wydobyciu, a działki te są czasowo przedmiotem rekultywacji. W ocenie organów i sądów administracyjnych rekultywacja, której obowiązek wynika z ustaw, pozwala uznać traktowanie danego gruntu, jako pewnego rodzaju przestrzeni służącej wykonywaniu

${ }^{13}$ L. Etel, Ustawa o podatkach i opłatach lokalnych. Komentarz, [w:] Podatek od nieruchomości, wyd. 3, Warszawa 2009. 
określonego rodzaju działalności gospodarczej ${ }^{14}$. Nie oznacza to jednak, że posiadanie koncesji obejmującej grunty rolne każdorazowo doprowadzi do opodatkowania wszystkich takich gruntów podatkiem od nieruchomości. Pojęcie rekultywacji jest bowiem ściśle zdefiniowane przez ustawodawcę i odnosi się jedynie do nadania lub przywrócenia gruntom zdegradowanym albo zdewastowanym wartości użytkowych lub przyrodniczych przez właściwe ukształtowanie rzeźby terenu, poprawianie własności fizycznych i chemicznych, uregulowanie stosunków wodnych, odtworzenie gleb, umocnienie skarp oraz odbudowanie lub zbudowanie niezbędnych dróg ${ }^{15}$. Inne będą natomiast skutki podatkowe, gdy na części gruntów objętych koncesją, np. na wydobycie, podatnik nie wykonuje żadnych czynności zmierzających do osiągania przez niego przychodu, nie są poddane rekultywacji a faktycznie są używane na cele rolne i służą uprawie rolnej.

Jak już wcześniej było podkreślone, nie można bowiem przyjąć, że ten sam grunt może być jednocześnie klasyfikowany jako grunt wykorzystywany na potrzeby prowadzenia produkcji rolnej (leśnej) i w tym samym czasie i zakresie także na potrzeby prowadzenia działalności gospodarczej. Doszłoby bowiem wówczas do zbiegu podstaw powstania obowiązku podatkowego, co jest sprzeczne z konstytucyjną zasadą zakazu podwójnego opodatkowania tego samego przedmiotu opodatkowania.

\section{WNIOSKI}

Podsumowując, dopiero rozpoczęcie działalności innej niż rolnicza na gruntach sklasyfikowanych w ewidencji jak rolne (faktyczne zajęcie tych gruntów) pozwala na jego opodatkowanie podatkiem od nieruchomości. Ustawodawca celowo różnicuje bowiem pojęcia gruntu zajętego i gruntu związanego z prowadzeniem działalności. Wykładnia pojęcia „zajęte na

${ }^{14}$ Np. wyrok NSA z dnia 9 września 2015 r., sygn. 3223/13, w którym sąd uznał, iż: „Czynności rekultywacyjne stają się częścią składową działalności gospodarczej w zakresie wydobywania kopalin, od chwili uzyskania koncesji. Do czasu zakończenia rekultywacji stwierdzonej ostateczną decyzją właściwego organu administracyjnego grunty te są nie tylko związane z prowadzeniem działalności gospodarczej, ale także faktycznie zajęte na jej prowadzenie, co w świetle przepisów: art. 2 ust. 1 i 2 w związku $\mathrm{z}$ art. 1 a ust. 1 pkt 3 i 1 a ust. 1 pkt 4 u.p.o.l. powoduje, iż podlegają opodatkowaniu podatkiem od nieruchomości według stawek najwyższych".

${ }^{15}$ Por. art. 4 pkt 18 ustawy z dnia 3 lutego 1995 r. o ochronie gruntów rolnych i leśnych; (Dz.U. z 2004 r. Nr 121, poz. 1266 z późn. zm.). 
prowadzenie działalności gospodarczej” wskazuje, że do opodatkowania podatkiem od nieruchomości nie wystarcza samo ich posiadanie (nawet jeśli jest ono powiązane $\mathrm{z}$ objęciem tych gruntów koncesją czy $\mathrm{z}$ intencją przyszłego zabudowania lub sprzedaży tych gruntów).

Ustawodawca tworząc przepisy dotyczące opodatkowania gruntów nie nałożył obowiązku prowadzenia działalności rolniczej na właścicieli gruntów rolnych i zdecydował, że warunkiem opodatkowania podatkiem rolnym jest jedynie posiadanie odpowiednio sklasyfikowanych nieruchomości ${ }^{16}$. Tym samym, niemożliwe jest jednoczesne opodatkowanie danego gruntu zarówno podatkiem rolnym jak i od nieruchomości. W sytuacji, gdy przedsiębiorca nie prowadzi działalności rolnej na gruncie rolnym, każdorazowo należy zbadać czy rzeczywiście w jego sytuacji doszło do faktycznego i fizycznego zajęcia gruntu na działalność gospodarczą. Brak takiej analizy prowadziłby bowiem do wymierzania podatków w oparciu o stan faktyczny niezgodny z rzeczywistością.

\title{
BIBLIOGRAFIA
}

Brzeszczyńska S., Sprzedaż gruntów rolnych przez dewelopera, MOPOD 2014, nr 3, s. 11. Dowgier R., Glosa do wyroku TK z dnia 12 grudnia 2017 r., SK 13/15., ZNSA 2018/3, s. $133-142$.

Etel L., Ustawa o podatkach i opłatach lokalnych. Komentarz, [w:] Podatek od nieruchomości, wyd. 3, Warszawa 2009.

Podedworna I., Wojtowicz-Janicka K., Grunty jako przedmiot podatku od nieruchomości [online], 23.04.2018 21:20, https://sip.lex.pl/\#/publication/469833093 (dostęp: 25.04.2018).

Zaniewicz E., Wplyw ewidencji gruntów i budynków na podatek od nieruchomości, https:// sip.lex.pl/\#/publication/469910859/zaniewicz-edyta-wplyw-ewidencji-gruntow-i-budynkow-na-podatek-od-nieruchomosci?cm=RELATIONS (dostęp: 20.04.2018).

\begin{abstract}
The article discusses issues related Property Tax on farmlands occupied for business activity. The concept farmlands occupied for business activity is not regulated directly in Polish law. Thus, the article analyzes court rulings, system interpretation and doctrines' view on this topic.
\end{abstract}

Keywords: property tax, farmlands, business activity

${ }^{16}$ S. Brzeszczyńska, Sprzedaż gruntów rolnych przez dewelopera, „Monitor Podatkowy" 2014, nr 3, s. 11. 